\title{
EEG Characteristic Extraction Method of Listening Music and Objective Estimation Method Based on Latency Structure Model in Individual Characteristics
}

\author{
Shin-ichi Ito Non-member (Tokyo University of Agriculture and Technology, s.ito@mi.lab.tuat.ac.jp) \\ Yasue Mitsukura Member (Tokyo University of Agriculture and Technology, mitsu_e@cc.tuat.ac.jp) \\ Hiroko Nakamura Miyamura Non-member (Tokyo University of Agriculture and Technology, \\ miyamura@cc.tuat.ac.jp)
}

Takafumi Saito Non-member (Tokyo University of Agriculture and Technology, txsaito@cc.tuat.ac.jp)

Minoru Fukumi Member (University of Tokushima, fukumi@is.tokushima-u.ac.jp)

Keywords: electroencephalogram, individual characteristics, latency structure model, real-coded genetic algorithms, visualization

We attempt to analyze electroencephalogram (EEG) signals from one measurement position that is Fp1 of the international 10-20 system. Fp1 is famous for obtaining the human sensibility by hearing stimulus. An EEG is characterized by the unique and individual characteristics. Little research has been done to take into account the individual characteristics when analyzing the EEG signals. Often the EEG has frequency components which can describe most of the significant characteristics. Then there is the difference of importance between the analyzed frequency components of the EEG. We think that the important difference means the individual characteristics. In this paper, we propose a new EEG extraction of characteristic vector by a latency structure model in individual characteristics (LSMIC). The LSMIC is the latency structure model, which has personal error as the individual characteristics, based on normal distribution. The real-coded genetic algorithms (RGA) are used for specifying the personal error that is unknown parameter. Moreover we propose an objective estimation method that plots the extracted characteristic vectors on a visualization space (three-dimensional space). The visualization space consists of three axes that are a euclidian distance, a cosine distance, and a correlation coefficient.

The performance of the proposed method is evaluated using a realistic simulation and applied to a real EEG data. The subjects listen to four different kinds of music, namely rock (red color), classical (blue color), healing (pink color), and Japanese ballad (green color). This study compares the performance of the cross-factor analysis model and the LSMIC. Fig.1 shows an example of the results. The result of the LSMIC has a low dispersion among the extracted characteristic vectors, when the subject listened to same music, and a high dispersion among the extracted characteristic vectors, when the subject listened to different music, relative to the

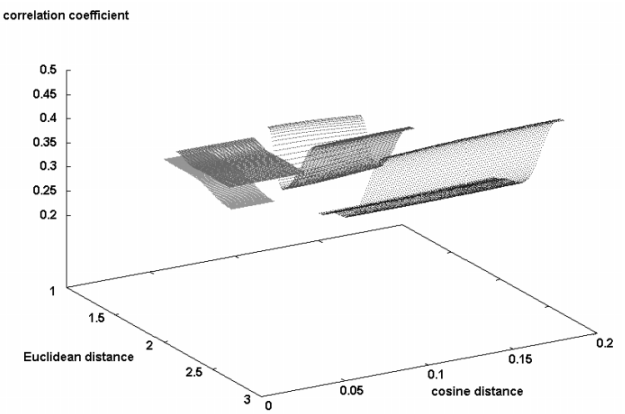

(a) LSMIC

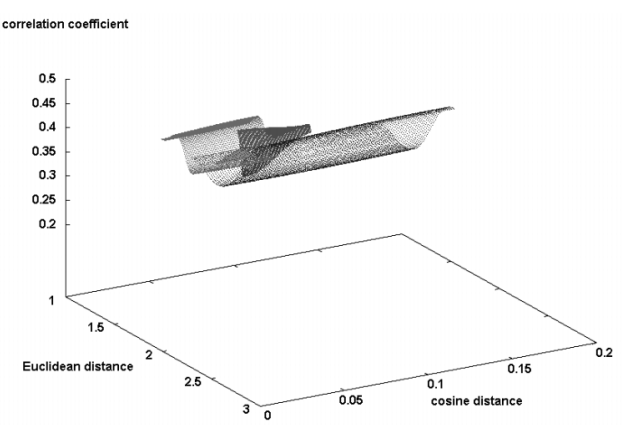

(b) Cross-factor analysis model

Fig. 1. An example of the results

result of the cross-factor analysis model. Our simulation results suggest that specifying the individual characteristics is significant for EEG characteristic extraction, because the difference of the LSMIC and the cross-factor analysis model is existence or nonexistence of personal error. From the result, we can confirmed that the proposed method works well. 


\title{
個人特性を考慮した潜在構造モデルによる 音楽聴取時の脳波特徵抽出法と客観的評価方法
}

\author{
非会員 伊藤 伸一* \\ 正 員 満倉 靖恵* \\ 非会員 宮村 (中村) 浩子* 非会員 斎藤 隆文* \\ 正員福見 稔**
}

\begin{abstract}
EEG Characteristic Extraction Method of Listening Music and Objective Estimation Method Based on Latency Structure Model in Individual Characteristics

Shin-ichi Ito*, Non-member, Yasue Mitsukura*, Member, Hiroko Nakamura Miyamura*, Non-member, Takafumi Saito*, Non-member, Minoru Fukumi**, Member
\end{abstract}

EEG is characterized by the unique and individual characteristics. Little research has been done to take into account the individual characteristics when analyzing EEG signals. Often the EEG has frequency components which can describe most of the significant characteristics. Then there is the difference of importance between the analyzed frequency components of the EEG. We think that the importance difference shows the individual characteristics. In this paper, we propose a new EEG extraction method of characteristic vector by a latency structure model in individual characteristics (LSMIC). The LSMIC is the latency structure model, which has personal error as the individual characteristics, based on normal distribution. The real-coded genetic algorithms (RGA) are used for specifying the personal error that is unknown parameter. Moreover we propose an objective estimation method that plots the EEG characteristic vector on a visualization space. Finally, the performance of the proposed method is evaluated using a realistic simulation and applied to a real EEG data. The result of our experiment shows the effectiveness of the proposed method.

キーワード：脳波，個人特性，潜在構造モデル，遺伝的アルゴリズム，可視化

Keywords: electroencephalogram, individual characteristics, latency structure model, real-coded genetic algorithms, visualization

\section{1. まえがき}

近年，脳波は操作に特別な動作が不要なマンマシンイン タフェースに成り得ると期待され，これらを用いたインタ フェースの研究が盛んに行なわれている(1)(2)。また，脳波 で人間の心理的・生理的な変化の計測および感性や嗜好の 取得を目的とした研究が行なわれ始めている。しかし，脳 波は複数の要因が複雑に絡み合った時系列信号であり，脳 波の計測部位によって出現する脳波が異なり, 各周波数成 分の持つ意味合いも異なる。さらに, 脳波の出現パターン

\footnotetext{
* 東京農工大学

干 184-8588 東京都小金井市中町 2-24-16

Tokyo University of Agriculture and Technology

2-14-26 Naka-cho, Koganei, Tokyo 184-8588

** 徳島大学

干 770-8506 徳島県徳島市南常三島町 2-1

The University of Tokushima, 2-1 Minami-josanjima, Tokushima 770-8506
}

を示す特徵波に個人差がある。脳波の特徵を抽出する際に は,これらを考慮しなければならない。

これまでの研究における脳波の計測部位は複数チャンネ ル (以後 ch と略記する) がほとんどである。これは単一 ch の情報のみを用いると一部の chにおいて, 特徴波が出現し ないといった出現状況のばらつきや，パワーの大きな背景 波が重なって出現することにより, 特徵波の検出が困難に なる場合がしばしば起こることに起因している(2)(3)。しか しながら, 長年の研究成果により, 心理的・生理的な変化 を示す脳波は前頭葉部分に強く現れるなど, 各計測部位に おける脳波の意味づけが明確化されつつある。さらに，マ ンマシンインタフェースを考慮すると, 複数 ch の脳波計測 は簡便とは言い難く実用化しにくい(1)(2)。単一 ch 情報の みを用いた脳波の特徵抽出精度の向上が必要であると思わ れる。

ところで, 音楽聴取時の心的変化の観測は, 長時間の脳 波計測が必要であり，そのときの脳波は音楽刺激により誘 
発される成分，余韻により自発的・偶発的に出現する成分， そしてそれ以外のノイズ成分が重なり合っていると考えら れる。周波数分析された脳波は，各周波数スペクトルの時 間推移の相関関係を考慮することで脳波の特徴データ抽出 を行なっている研究があり，長時間の脳波計測において，そ の有効性も検証されている(4)(5)。脳波の周波数成分には, 特徵が強く現れている周波数成分と, そうでない周波数成 分が個人別に存在する。著者らは，この個人差を個人特性 であると判断している(2)。しかし従来法では，脳波の個人 特性が十分に考慮されているとは言い難い。個人特性を考 慮しない場合，特徵抽出精度が悪化することは一般的に大 きな問題とされている。

さらに，脳波の特徵抽出精度の評価は，脳波パターンの 分類問題に当てはめることで行なわれることが少なくない。 しかし，人間の心的変化などのあいまいな言葉でしか表現 できない事例には，適しているとは言い難い。これらのこ とから，客観的評価を行なう必要がある。

本論文では，次の 4 点に着目した手法を提案する。まず 第 1 点目は，単一 ch 情報による脳波の特徵抽出である。 単一 ch 情報のみで十分な特徵抽出精度が実現できた場合， 脳波インタフェースの研究が飛躍的に進展すると考えられ る。また, 複数 ch 情報への応用も可能である。第 2 点目は, 個人特性を考慮した潜在構造モデル (Latency Structure Model in Individual Characteristics : LSMIC)の導入で ある。周波数分析された脳波の各周波数スペクトルの時間 推移の相関関係より, 直接的な観測データから得られるこ とが困難な情報を抽出する手法を用いた研究があり，その 有効性も検証されている(2)(4)(5)。同様の効果を持つものに 潜在構造モデル (Latency Structure Model : LSM) があ る。従来の LSM では，個人特性が考慮されているものは あまり見られない。本論文では, 一般的な LSM のモデル 誤差を個人誤差 (personal error) と定義することで，脳波 の “個人差”を考慮したモデル (LSMIC) を提案する。第 3 点目は，実数值遺伝的アルゴリズム (Real-coded Genetic Algorithm : RGA) の導入である。脳波の個人差が未知の パラメータであるため, LSMIC の個人誤差成分は，一意に 決定することができない。そこで，最適な個人誤差成分を 決定する必要がある。なお， RGA は様々な分野において， その有効性が検証されている最適化手法の 1 つである ${ }^{(6)}$ 。 本論文では，個人誤差成分の決定を行なう上で探索法とし てGA を採用している。第 4 点目は，可視化空間を用いた 客観的評価方法の導入である。可視化空間は, 人間が直接 的に把握可能な $2 \sim 3$ 次元空間を意味し(7) (9), 主成分分析, 自己組織化マップ，多次元尺度法などの次元削減技術によっ て作成されるとこがほとんどである (8)(9)。しかし，いかな るデータに対しても適用可能な写像を構成することは現在 のところ不可能である ${ }^{(9)}$ 。本論文では，3 種類の距離関数 を軸とする 3 次元空間へ射影する方法を提案する。

次節以降では，まず，脳波の計測方法について述べる。 次に，個人特性を考慮した潜在構造モデル (LSMIC) につ
いて述べる。さらに，遺伝的アルゴリズムを用いた最適な 個人誤差の推定による脳波の特徵抽出法と, 客観的評価を 行なうための可視化空間について述べ，実データを用いた 実験により，提案手法の有効性について考察する。最後に， 本論文をまとめる。

\section{2. 脳波計測}

本論文では，脳波インタフェース応用の一環として，音 楽刺激が人間に与える心理的・生理的効果を利用した脳の 活動状態および心的変化をコントロールするシステムの構 築を本研究チームの最終目標としている。このシステムは 脳波を指標に, ユーザの望む脳の活動状態に誘導すること が期待できる音楽を自動で選曲し, 選曲された音楽を聴く ことで, 脳波 (脳の活動状態および心的変化) をコントロー ルしようとするシステムである。また，このシステムの構 築にあたって重要となるのは, 音楽刺激による脳波の変化 に関する分析である。そこで本論文では，音楽刺激による 脳波の変化の計測および特徴抽出を行なう。

$\langle\mathbf{2} \cdot \mathbf{1}\rangle$ 聴 取曲 本論文では，ロック (rock music), 演歌 (Japanese ballad music), クラシック (classical music), 癒し系 (healing music) の 4 種類の音楽の系統を複数 回聴いてもらっている。聴取曲はアンケート調査により選 択した。アンケートはアーティストおよび曲に対して, 各々 ロック・ポップス・演歌・癒し系・クラシックの計 5 種類の 音楽の系統に分類してもらうものである。そして，このア ンケートを被験者を含む 20 代前半の男女を対象に計 20 人 に行ない, 20 人が完全に一致した音楽の系統に対する聴取 曲を選択している。なお，現在流行となるポップスは，ロッ クに近い曲からクラシックに近い曲とが存在し, 個人によっ ても印象が著しく異なるため，可視化空間に投影した場合， 一様に分布されることが容易に想像できることから，聴取 曲から除外している。

$\langle 2 \cdot 2\rangle$ 計測状況と採取データ＼cjkstart本論文の被験者は聴覚 正常であるとともに，心身ともに正常な 20 歳から 24 歳の 健常者 4 人 (男子 3 人, 女子 1 人) である。脳波計は, 実用 的な環境下での計測を可能とする脳力開発研究所の Brain Builder を使用した。概形は $120 \mathrm{~mm}(\mathrm{~W}) \times 135 \mathrm{~mm}(\mathrm{D}) \times$ $35 \mathrm{~mm}(\mathrm{H})$ とコンパクトなものであり, 従来の装置に比べ て被験者に与える精神的・生理的な負担は極めて小さい。 また，電極はへッドバンドに固定されていて，計測部位は 図 1 に示す国際 10-20 法における電極配置 Fp1(左前頭葉 部分) にあたる箇所であり, 左耳朵を基準電極とする単極 誘導法により計測している。Fp1を選んだ主な理由として， 人間の生理的 - 心理的変化は脳の前頭葉部分の脳波に多く

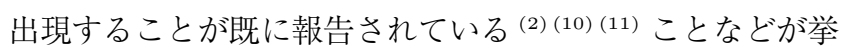
げられる。

従来の心的变化の分析は， $\alpha$ 波や $\beta$ 波などのバンドに区 切り,これらの出現頻度を計算するといった比較的あらい 評価方法である。本論文では，より細かな分析を行なうた めに， $1 \mathrm{~Hz}$ 間隔のバンドに区切っている。前処理として， 


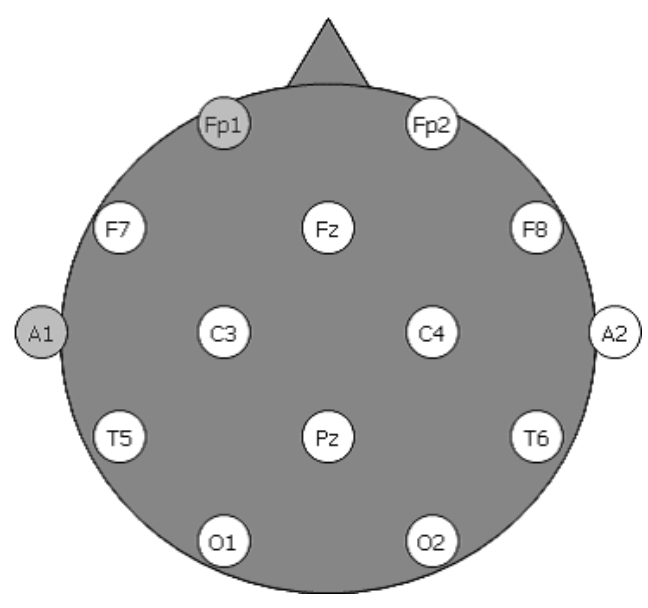

図 1 国際 10-20 法

Fig. 1. International 10-20 system

付属の脳波解析ソフト (MinDSensorII) を用いている。解 析ソフトから得られるデー夕は，1秒間の脳波を高速フー リエ変換 (サンプリング周波数： $128 \mathrm{~Hz}$ ) し， $1 \mathrm{~Hz}$ 間隔で $24 \mathrm{~Hz}$ まで周波数分析されたものである。この脳波計はバ ンドパスフィルタ (4-22Hz:96dbでフラット，オクターブご とに $6 \mathrm{db}$ ダウン) を用いているため，主要な周波数成分は $4-22 \mathrm{~Hz}$ としている。計測は音楽による影響が最も強く現れ るように以下の条件で行なっている。計測状況はいずれの 被験者に対しても，若干の雑音のある計算機室内で PC 用 の椅子に楽な姿勢で腰を掛けた状態で行なっている。また， 耳にヘッドホン，左耳架にセンサ・クリップ，額にセンサ・ バンドを付着し，計測中は目を閉じてなるべく体は動かさ ないという条件下で行なった。

\section{3. 個人特性を考慮した潜在構造モデル}

計測器から得られる $4-22 \mathrm{~Hz}$ における離散時間時系列群 $Y=Y(f) \equiv\left\{y^{(t)}(f) ; 1 \leq t \leq T\right\}$ は，音楽刺激による影響 を表わす成分 $S=S(f) \equiv\left\{s^{(t)}(f) ; 1 \leq t \leq T\right\}$ とそれ以外 の成分 $N=N(f) \equiv\left\{n^{(t)}(f) ; 1 \leq t \leq T\right\}$ で示すことがで きる。

$$
Y=S+N
$$

音楽聴取時の単一 $\mathrm{ch}$ から観測される脳波には，音楽刺激 により誘発された成分，余韻により自発的・偶発的に現れ た成分，他の刺激により誘発された成分，音楽刺激に関連 性のない偶発的な成分，そして瞬きなどのノイズ成分が重 なっていると考えられる。本論文では，目を閉じてなる心゙ く体を動かさない状態で，かつ音楽以外の外部刺激を与え ない状態で脳波計測を行なっているため，他の刺激により 誘発された成分および瞬きなどのノイズ成分は比較的抑制 された状態であると考えられる。したがって (1) 式における $N$ は，音楽刺激に関連性のない自発的・偶発的な部分，混 入しているノイズ部分，そして音楽刺激以外の誘発反応の 集合体であると考えられる。本論文では，各周波数成分の
離散時間推移を構成する要素の中で，音楽刺激による影響 を示す潜在因子を周波数成分間の相関性により, 統計学的 モデルから導出する。 $Y$ を正規分布に基づき $\operatorname{Ave}(Y)=0$, $\operatorname{Var}(Y)=I$ に変換すると,

$$
\tilde{Y}=F \Lambda^{T}+U \Psi .
$$

となる。このとき $F=F_{i} \equiv\left[F_{1}, F_{2}, \cdots, F_{n}\right](1 \sim \mathrm{n}$ は固有 值の大きい順) は $S$ の成分と, $N$ の成分の両方を含む潜 在因子のスカラー値, $\Lambda=\Lambda_{i} \equiv\left\{\Lambda_{i j} ; 1 \leq i \leq n, 4 \leq j \leq 22\right\}$ は潜在因子の荷重べクトルを示している。 $U=U_{f} \equiv$ $\left[U_{4}, U_{5}, \cdots, U_{22}\right]$ は $N$ の成分の一部で形成される各周波 数成分独自にみられる固有の変動を表わす独自因子のスカ ラー値, $\Psi=\Psi_{f} \equiv\left[\Psi_{4}, \Psi_{5}, \cdots, \Psi_{22}\right]$ は独自因子の荷重べ クトルを示している。一般的な LSM の $\Psi$ はモデル誤差を 意味する。本論文では， $\Psi$ を個人誤差 (personal error) と 定義する。そのため, 抽出される特徵べクトル $(\Lambda)$ は, 個 人特性が考慮されていると判断できる。

変換された離散時間時系列群 $\tilde{Y}$ の相関行列は,

$$
R(\tilde{Y})=\frac{1}{A} \tilde{Y}^{T} \tilde{Y} .
$$

で定義される。なお， $A$ は総周波数成分数 $(4-22 \mathrm{~Hz}: 19)$ を 意味する。(2), (3) 式より

$$
R(\tilde{Y})=\frac{1}{A}\left(\Lambda F^{T}+\Psi U^{T}\right)\left(F \Lambda^{T}+U \Psi\right) . \cdots \cdots
$$

ここで互いの因子間が無相関であると仮定すると，

$$
\begin{aligned}
& \frac{1}{A} F^{T} F=I, \frac{1}{A} U^{T} U=I, \\
& F^{T} U=0 . \cdots \ldots \ldots \ldots \ldots
\end{aligned}
$$

となり (4) 式は,

$$
R(\tilde{Y})=\Lambda \Lambda^{T}+\Psi^{2} .
$$

となる。ここで前述より $\Psi^{2}$ は各周波数成分の独自性を対 角成分とする対角行列である。

$$
R^{\dagger}(\tilde{Y})=R(\tilde{Y})-\Psi^{2}
$$

と表わすと，

$$
R^{\dagger}(\tilde{Y})=\Lambda \Lambda^{T} .
$$

という関係を得ることができる。 $\Lambda$ は (8) 式を固有值問題 に当てはめ, 固有分解することで求めることができる。

音楽刺激が最も影響を与えるであろう実験条件において， 音楽刺激による影響を表わす特徵べクトルは，潜在因子の 中で最も寄与率 (固有值) を高くする固有べクトルである可 能性が高い。さらに，周波数分析された脳波の周波数成分 間の相関性が最も強いと想定できる。なぜなら，単一の周 波数成分のみで音楽刺激による影響が表わされることは考 えにくいと判断することが妥当だと思われるからである。 本論文では， $F_{1}$ は少なくとも音楽刺激による影響の要素が 含まれていると仮定し， $\Lambda_{1}$ を特徵べクトルとする。図 2 に 個人特性を考慮した潜在構造モデル (LSMIC) を示す。 


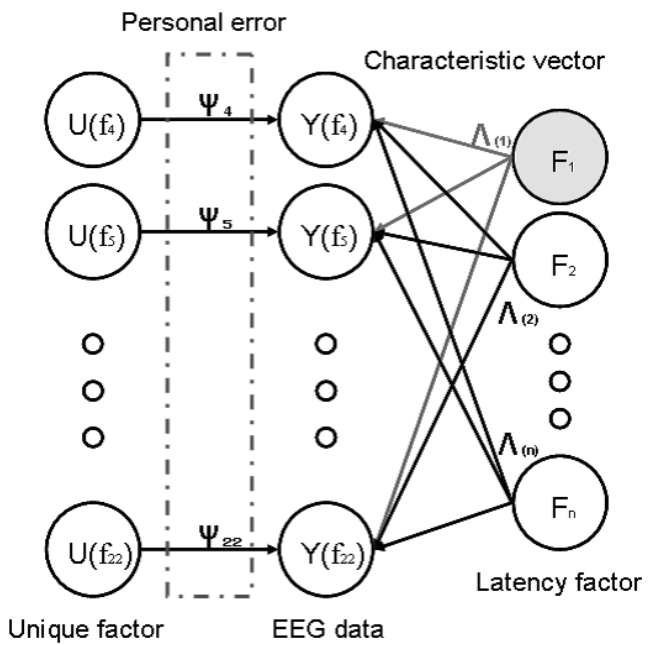

図 2 個人特性を考慮した潜在構造モデル (LSMIC)

Fig. 2. Latency structure model in individual characteristics

\section{4. 最適な個人誤差の推定による脳波の特徵抽出法 と客観的評価空間}

本論文では，RGA により最適な個人誤差 $(\Psi)$ を推定し， 推定された個人誤差を用いて，固有分解により特徵べクト ル $(\Lambda)$ を抽出する。図 3 に最適な個人誤差べクトルの推定 と脳波の特徵ベクトル抽出法の流れを示す。図 3 に示すよ うに，まず，初期化 (Initialization) として決められた数の 個体が生成される。RGA を構成する各個体の染色体は図 4 に示すように 1 次元で表現され，各遺伝子は $0.0 \sim 1.0$ の 実数值を持つ。個体の遺伝子は各周波数成分に対する独自 因子ベクトルと 1 対 1 で対応しており，その遺伝子の值が 各の推定值を表わしている。次に，推定されたを(8) 式に 代入し，近似相関行列 $R^{\dagger}$ を計算する。さらに，近似相関 行列 $R^{\dagger}$ を固有分解することで，特徴べクトル $\left(\Lambda_{1}\right)$ を求め る。なお固有分解には, 経験的に重心法を用いることにし た。以上の操作を現世代すべての個体に対して行なう。最 後に現世代すべての個体の適応度から，選択，交叉や突然 変異を行ない, 次世代の個体を生成する。以上の操作を終 了条件が満たされるまで行ない，終了条件が満たされた世 代の個体の中で，適応度の最も高い個体が示す染色体を最 適解とする。

$\langle\mathbf{4} \cdot \mathbf{1}\rangle$ 適応度の計算方法 本論文で用いる適応度関 数を以下に示す。

$$
\text { Fitness }=1-\frac{\sum_{p}^{P} \sum_{j}^{Y} \sum_{i}^{X}\left(V_{p, j, i}-G_{p, j}\right)^{2}}{P * X} .
$$

\begin{tabular}{ll}
\hline$P:$ & The number of music genre \\
$X:$ & The number of listnening to each music genre \\
$Y:$ & The number of frequency components \\
$V_{p, j, i}:$ & $\Lambda_{1}$ of each data patterns \\
$G_{p, j}:$ & Average vector of each music genre \\
\hline
\end{tabular}

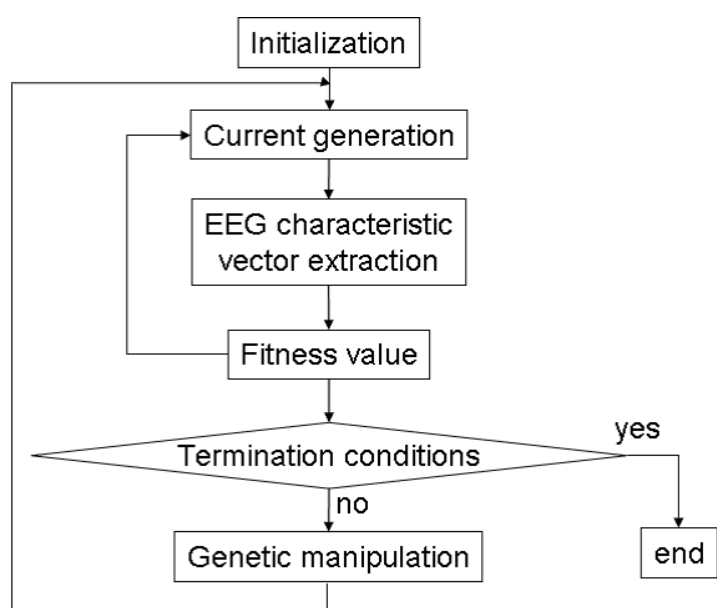

困 3 最適な個人誤差の推定と脳波の特徵抽出法 の流れ

Fig. 3. Flowchart of the optimum personal error estimation and the EEG characteristic vector extraction method

\begin{tabular}{cccc|ccc|c|}
\hline 0.87 & 0.75 & 0.86 & & $\cdots$ & 0.43 & 0.95 & 0.72 \\
\hline & $\uparrow$ & & & & $\uparrow$ & $\uparrow$ \\
& & & & & $\uparrow$ & $\uparrow$ \\
$\Psi_{4}$ & $\Psi_{5}$ & $\Psi_{6}$ & $\ldots$ & & $\Psi_{20}$ & $\Psi_{21}$ & $\Psi_{22}$ \\
$(4 \mathrm{~Hz})(5 \mathrm{~Hz})(6 \mathrm{~Hz})$ & $\ldots$ & & $(2 \mathrm{~Hz})(21 \mathrm{~Hz})(22 \mathrm{~Hz})$
\end{tabular}

図 4 染色体の構造

Fig. 4. The structure of chromosome

$P, X, Y$ はそれぞれグループ数 (聴取曲パターン数), 各グループにおけるデータパターン数 (聴取回数), そして 周波数成分数 $\left(4-22 \mathrm{~Hz}: 19\right.$ 個) を意味する。 $V_{p, j, i}$ は抽出さ れた特徴ベクトル， $G_{p, j}$ は各グループに属する全データパ ターンの平均ベクトルを示している。本論文では，同曲聴取 時の特徴ベクトルは少なくとも, 他曲聴取時の特徵べクト ルと比べて類似するとみなし, グループ内の特徴ベクトル 間の距離が短くなるほど，適応度が高くなるように設定し ている。なお距離計算にはユークリッド距離を用いている。

$\langle\mathbf{4} \cdot \mathbf{2}\rangle$ 遺伝子操作 遺伝子操作には，選択・淘汰処 理, 交叉，そして突然变異を用いる。選択・淘汰処理には エリート保存戦略 (elite strategy) を用いている。まず, 現 世代のすべての個体 (X 個) に対して適応度の高い順に $\mathrm{N}$ 個を選び出し，エリートとして次世代に残す個体とする。 なお初期 (第一世代) はランダムに生成する。次に現世代 の個体群から 2 つ親個体をランダムに取り出し，交叉お よび突然変異により子個体を生成する。交叉にはグローバ ル探索法として二点交叉，局所探索法としてブレンド交叉

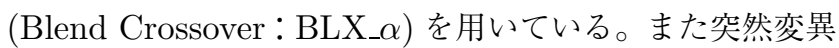
では，一定の確率で突然変異の対象となる個体の遺伝子に 乱数值 $(0.0$ ～1.0) を与える方法を用いる。以上の操作を $\mathrm{M}$ 回繰り返し，L個の子個体を生成する。生成された子個体 を適応度の高い順に並び替え, 上位 $(\mathrm{X}-\mathrm{N})$ 個の子個体を 
次世代の個体とする。

$\langle\mathbf{4} \cdot \mathbf{3}\rangle$ 終了条件 遺伝子操作は以下の 2 つの終了条件 のうち，どちらかが満たされるまで繰り返し演算を行なう。

·世代数が規定回数を超えた場合

・現世代の個体群の中で最も高い適応度を持つ個体の適 応度が 0.9 を超えた場合

$\langle\mathbf{4} \cdot 4\rangle$ 客観的評価空間 客観的評価空間は, 非類似 度 (ユークリッド距離), 類似度 (余弦距離), そして相関係 数を軸とする 3 次元の可視化空間である。可視化空間はク ラスター分析やパターン分類手法において，しばしば使用 される距離関数によって構成されている。ユークリッド距 離は，ピタゴラスの定理を基にして定義されている，ベク トルの大きさによって求められる一般的な距離関数であり, 多次元空間内での親近度を示す。余弦距離はべクトルの大 きさに左右されることがない, ベクトル間の角度によって 類似性を表現する距離関数である。相関係数はべクトルを 構成する変量ごとの結びつきの強さを示す類似尺度である。 空間内での位置づけは以下の通りである。可視化空間への 射影は，抽出されたすべての特徵べクトルから基準となる 平均ベクトルを算出し, 平均ベクトルと各特徵ベクトル間 の距離抢よび類似性を計算した結果を意味している。基準 ベクトルからの絶対距離 (類似度) を計算することで, 各特 徵べクトルの相対的な関係を目視することができると考え られる。また, 空間内で近傍領域に配置されるべクトルは, 親近度が高く, ベクトルの向きが類似し, さらにベクトル 間の相関が強い。つまり, 近傍領域に配置されるべクトル は，類似した特徵を持つべクトルであると判断できると考 えられる。な扮可視化空間は, 抽出された特徵べクトルの 客観的な評価を行なうことを目的としているため, 空間内 でのデー夕解析は行なわないこととする。

\section{5. 実 験}

$\langle\mathbf{5} \cdot \mathbf{1}\rangle$ 実験条件 被験者 4 人にロック，演歌，クラ シック, 癒し系の 4 種類の音楽の系統の代表曲を複数回聴 いてもらい，脳波計測により聴取曲が与えている影響を示 す特徵ベクトルを抽出する。さらに，客観的評価空間に射 影することで，提案手法の有効性を目視により検証する。

また本論文では，一般的な LSM の一つである直交因子 分析モデル (Cross-Factor Analysis Model : CFAM) を 用いた場合との比較実験により，LSMIC および特徽抽出 法の有効性を検証する。なお, CFAM では相互相関行列の 対角成分に 1.0(直交主因子分析モデル：Cross-principal component analysis model), 重相関係数の 2 乗 (Square Multiple Correlation : SMC), 㧍よび列の絶対值最大相関 係数 (Maximum Correlation Absolute Value : MCAV) が推定値としてしばしば用いられている。本論文では，こ れら 3 種類の推定值を用い, CFAM の解法により抽出さ れた特徵ベクトルと比較する実験を行なう。実験で用いた RGA の設定パラメータを表 1 に示す。

$\langle\mathbf{5} \cdot 2\rangle$ 実験結果 まず図 5,6 に, 被験者 4 人のうち
表 1 RGA の設定パラメータ

Table 1. Parameters of the RGA

\begin{tabular}{c|c}
\hline The maximum number of generations & 2500 \\
\hline The number of individuals & 300 \\
\hline The length of chromosome & 19 \\
\hline$\alpha$ value of BLX_ $\alpha$ & 0.0 \\
\hline Mutation rate & 0.05 \\
\hline
\end{tabular}

の 2 人における, CFAM と LSMIC の比較実験のサンプル 結果を示す。赤色はロック, 緑色は演歌, 青色はクラシッ ク, ピンク色は癒し系の曲を意味している。本論文では, 同 曲聴取時の特徵ベクトルは, 他曲聴取時の特徵ベクトルに 比べて類似する傾向があると仮説を立てている。そのため, 可視化空間内において, 各曲内の分散が小さいほど良好な 結果であると言える。LSMIC の結果は他の結果に比べて, 各曲内の分散が小さくなっている。さらに, 前述の仮説に も関わらず，曲間の分散が大きくなっている。LSMIC は LSM におけるモデル誤差を個人誤差と定義することで,「脳 波の個人差」による脳波のばらつき(ノイズ)が抑制されて いるため，比較的良好な結果を得ることができたと考えら れる。

次に, 図 7 に各被験者拐ける LSMIC の結果を示す。被 験者ごとに分布されている場所, 各曲内の分散, 曲間の分 散に明らかな違いがあることがわかる。また同曲を聴取し ている場合でも, 被験者ごとに心的に与える影響が異なり， 従来から示唆されている, 音楽が人間に与える影響の個人 差を示していると考えられる。さらに，可視化空間により 目視することができることから, 提案した可視化空間は音 楽刺激による影響を示す脳波の特徴抽出精度を, 客観的に 評価可能であることを示唆している。

最後に, 各被験者における RGA によって推定された $\Psi$ の值のサンプルを図 8 に示す。一般的な LSM において，モ デル誤差の大きなモデルは信頼性にそしいとされ，モデル 誤差が小さいほど良好なモデルであることを意味すると考 えられている。被験者ごとで $\Psi の$ 值は異なり，一部の被験

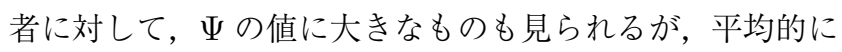
小さい值であることから，LSMIC は良好なモデルである と考えられる。

\section{6. まとめ}

本論文では，脳波インタフェースを考慮し，単一 $\mathrm{ch}$ 情報 による脳波の特徵抽出法と, 可視化空間を作成し抽出され た特徵ベクトルを客観的に評価する方法を提案した。脳波 の特徵抽出には, 一般的な LSM のモデル誤差を個人誤差 と定義したLSMIC を提案し，一意に決定することが困難 な個人誤差を RGAにより決定する方法を提案した。さら に, 異なる 3 つの距離関数を軸とする 3 次元の可視化空間 を作成し，特徴べクトルを投影する客観的評価方法を提案 した。また，実験により提案手法の有効性を検証し，比較 的良好な結果を目視で確認することができ，個人特性を考 


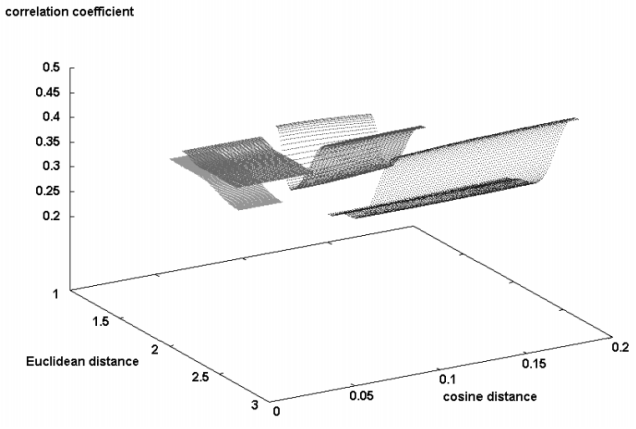

(a) LSMIC

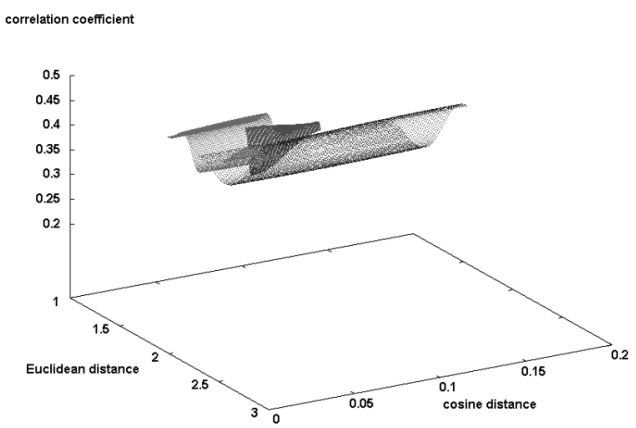

(c) Cross-factor analysis model by using SMC

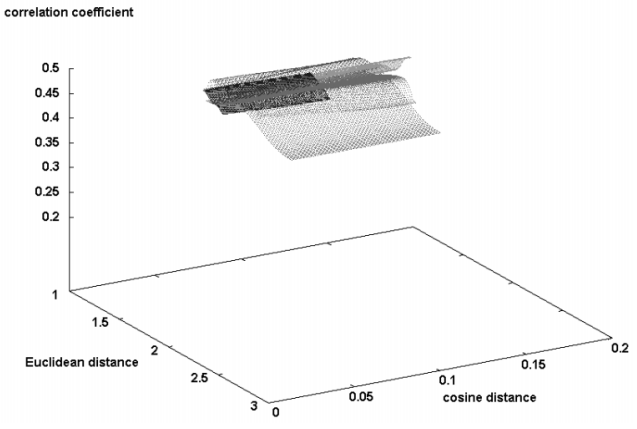

(b) Cross-principal component analysis model

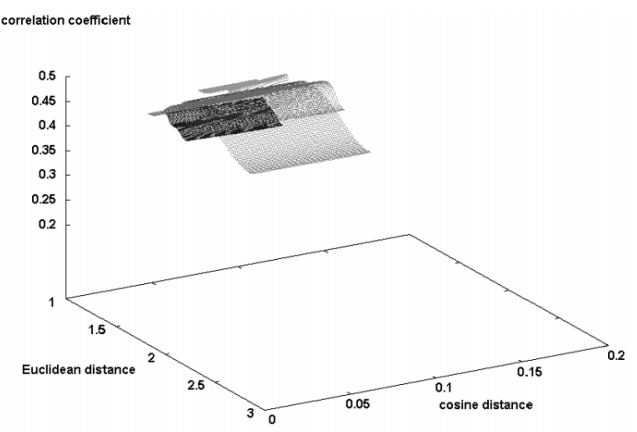

(d) Cross-factor analysis model by using MCAV

図 5 被験者 1 における比較実験結果

Fig. 5. Results of Subject 1

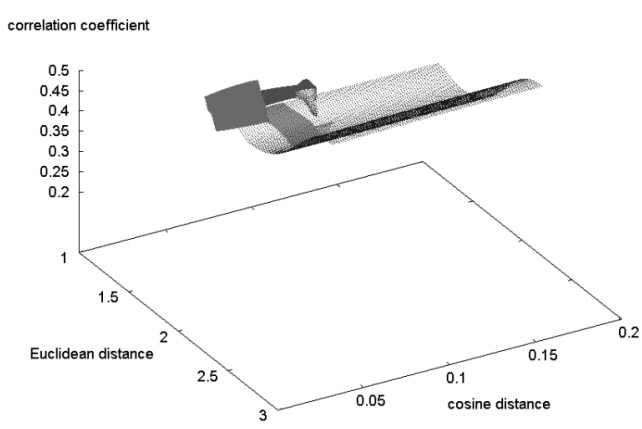

(a) LSMIC

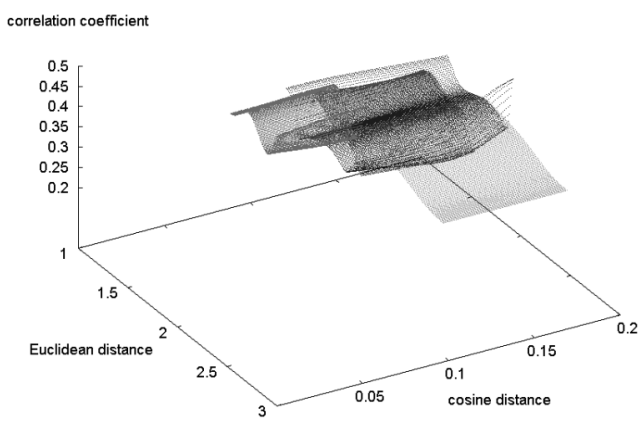

(c) Cross-factor analysis model by using SMC

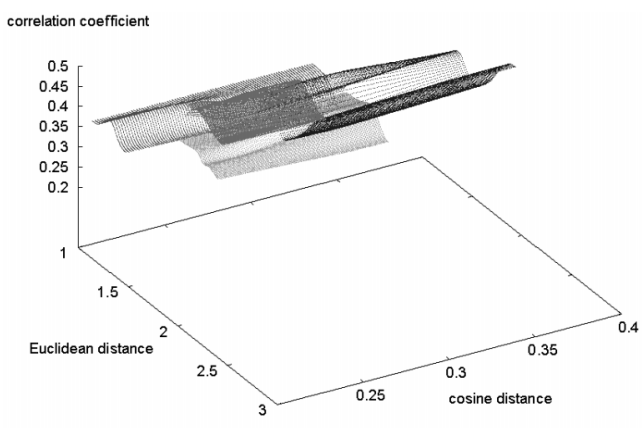

(b) Cross-principal component analysis model

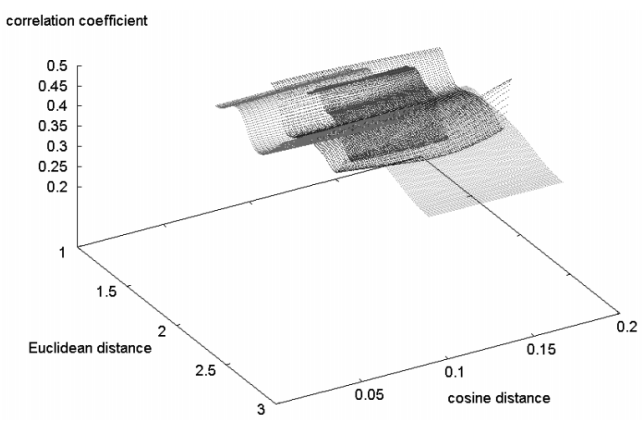

(d) Cross-factor analysis model by using MCAV

図 6 被験者 2 における比較実験結果

Fig. 6. Results of Subject 2

慮したモデルの有効性を検証することができた。

本論文では，曲間の分散が比較的大きくなるように，聴 取曲の選択をアンケートにより行なった。そこで，被験者
および聴取曲を増やすことで，より実用的になると考えら れる。また, LSMIC は正規分布に基づく線形モデルに個 人特性を考慮したものである。そこで，非正規性もしくは 


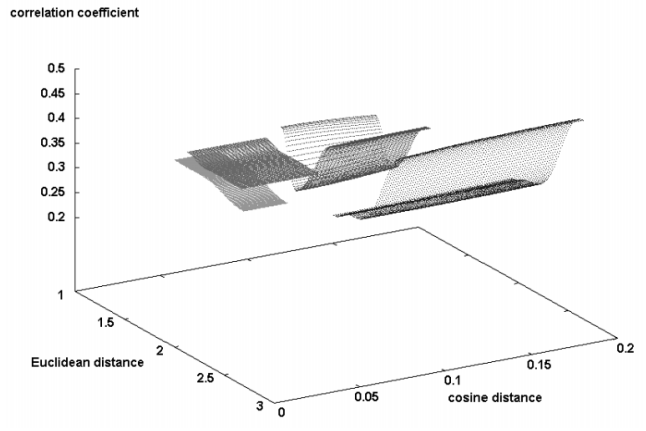

(a) Result of Subject 1

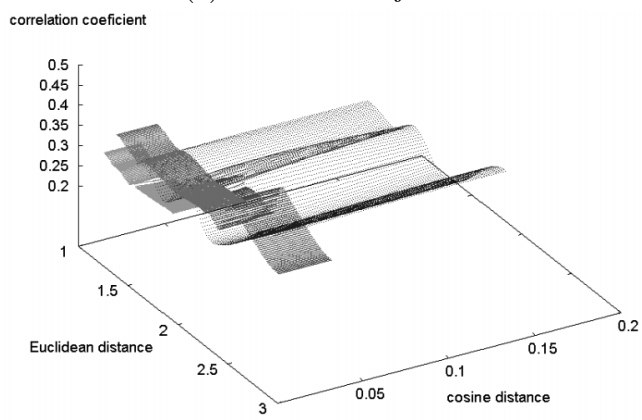

(c) Result of Subject 3

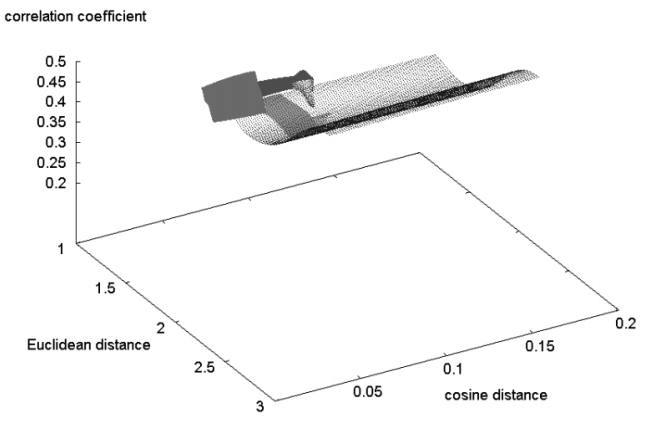

(b) Result of Subject 2

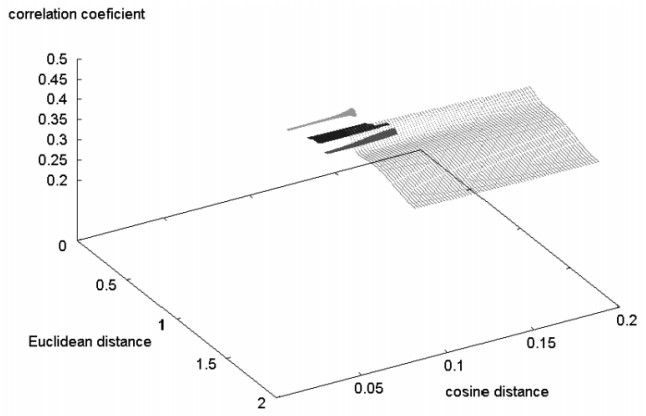

(d) Result of Subject 4

図 7 各被験者における LSMIC を用いた場合の実験結果

Fig. 7. Results of each subject by using LSMIC

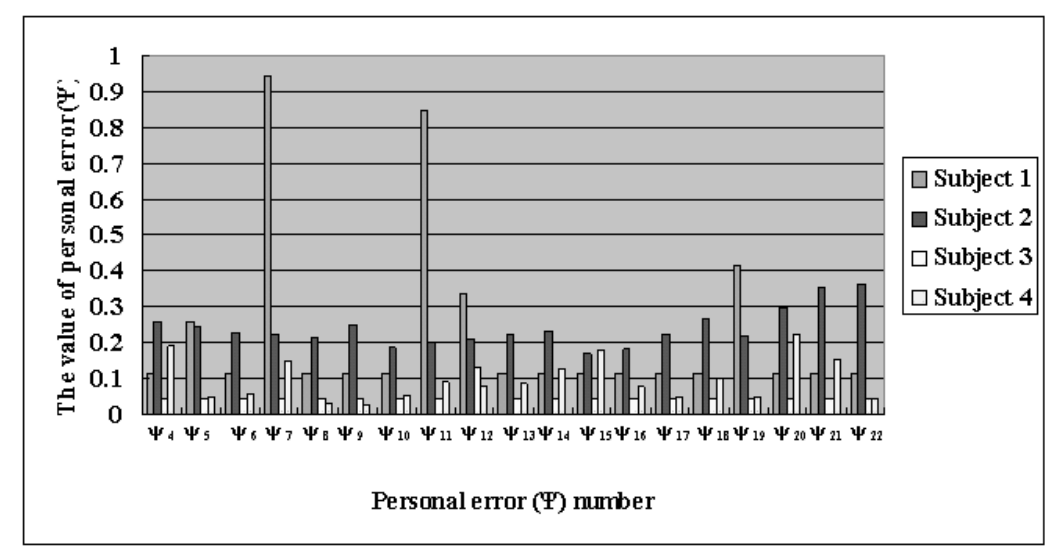

図 8 RGA によって推定された個人誤差

Fig. 8. Estimation of Personal error by using the RGA

非線形モデルへ拡張することで，より汎用性の高いモデル に成り得ると期待できる。

(平成 18 年 7 月 31 日受付, 平成 18 年 12 月 5 日再受付)

\section{文献}

(1) H. Tanaka and H. Ide: "Intention Transmitting by the SingleTrial MRCP Analysis", IEEJ Trans. EIS, Vol.122-C, No.5, pp.780-785 (2002-5) (in Japanese) 田中久弥・井出 英人：「単一試行の運動関連脳電位解析による意図 伝達システム」, 電学論, 122-C，5，pp.780-785 (2002-5)

(2) S. Ito, Y. Mitsukura, M. Fukumi, and N. Akamatsu: "Proposal of the EEG Analysis Method Using the Individual Characteristic of the EEG", IEEJ Tarns. EIS, Vol.124-C, No.6, pp.1259-1266 (2004-6) (in Japanese)
伊藤伸一・満倉靖恵・福見 稔・赤松則男:「脳波の個人特性を考慮した 脳波分析法の提案」, 電学論, 124-C, 6, pp.1259-1266 (2004-6)

(3) T. Shimada, T. Shina, and Y. Saito: "Auto-Detection of Characteristics of Sleep EEG Intergrating Multi Channel Information by Neural Networks and Fuzzy Rule", IEICE(DII), Vol.J81-D-II, No.7, pp.1689-1698 (1998) (in Japanese) 島田尊正・椎名 毅・斎藤陽一:「ニューラルネットワークとファジー ルールによる多チャンネル情報を結合した脳波特徵波の自動検出」, 信学論 (D-II), J81-D-II, No.7, pp.1689-1698 (1998)

(4) T. Katayama, E. Suzuki, and M. Saito: "Staging of Awake and Sleep Based on Feature Maps", IEICE (D-II), Vol.J77D-II, No.11, pp.2306-2313 (1994) (in Japanese)

片山貴文・鈴木穎二 · 斎藤正男 :「特徴写像による覚醒と睡眠の段 階付け」, 信学論 (D-II), J77-D-II, 11, pp.2306-2313 (1994)

(5) S. Yokoyama, T. Shimada, A. Takemura, T. Shiina, and Y. Saito: "Detection of Characteristic Wave of Sleep EEG by Principal Component Analysis and Neural-Network", IEICE (A), Vol.J76-A, No.8, pp.1050-1058 (1993) (in Japanese) 
横山幸生・島田尊正 ・ 竹村 淳・椎名 毅・斎藤陽一：「睡眠脳波の 主成分分析とニューラルネットワークによる特徵波検出」, 信学論 (A), J76-A，8，pp.1050-1058 (1993)

(6) S. Ito, Y. Mitsukura, M. Fukumi, and N. Akamatsu: "Neuro Rainfall Forecast with Data Mining by Real-Coded Genetical Preprocessing", IEEJ Trans. EIS, Vol.123, No.4, pp.817-822 (2003-4) (in Japanese)

伊藤征嗣・満倉靖恵・福見 稔・赤松則男：「実数值 GA を用いた データマイニングによるニューロ降雨予測システムの設計」, 電学 論, 123-C, 4, pp.817-822 (2003-4)

(7) A.K. Jain, R. Duin, and J. Mao: "Statistical pattern recognition: A review", IEEE Trans. PAMI, Vol.22, No.1, pp.4-37 (2000)

(8) K. Yamamoto, T. Yoshikawa, and T. Furuhashi: "A Proposal of Visualizztion Method for Multi-Dimensional Data Using Fuzzy Clustering Based on Multiple Discriminant Analysis", IEICE (D-II), Vol.J88-D-II, No.6, pp.975-984 (2005-6) (in Japanese)

山本康高・吉川大弘・古橋 武: 「判別分析を基準とするファジーク ラスタリングによる多次元データの可視化手法の提案」, 信学論, J88-D-II，6，pp.975-984 (2005-6)

(9) T. Suenaga, A. Sato, and H. Sakano: "Cluster Discriminant Analysis for Feature Space Visualization", IEICE (DII), Vol.J85-D-II, No.5, pp.785-795 (2002-5) (in Japanese) 末永高志・佐藤 新・坂野 鋭: 「クラス夕構造に着目した特徴空間の 可視化一クラス夕判別法一」, 信学論, J85-D-II，5，pp.785-795 (2002-5)

(10) N. Utsunomiya, H. Tanaka, and H. Ide: "Construction of Pleasantness Emotion Matrix by the Correlation Coeffcients of EEG", IEEJ Trans. EIS, Vol.122-C, No.2, pp.309-311 (2002-2) (in Japanese)

宇都宮直子・田中久弥・井出英人:「脳波の相互相関係数による快·不快 推定マトリクスの作成」, 電学論, 122-C, 2, pp.309-311 (2002-2)

(11) S. Tasaki, T. Igasaki, N. Murayama, and H. Koga: "Relationship between Biological Signals and Subjective Estimation", IEEJ Trans. EIS, Vol.122-C, No.9, pp.1632-1638 (2002-9) (in Japanese)

田崎新二・伊賀崎伴彦・村山伸樹 ·古賀広昭：「音楽鑑賞時における七 卜の感性と生体信号の関連性」, 電学論, 122-C, 9, pp.1632-1638 (2002-9)

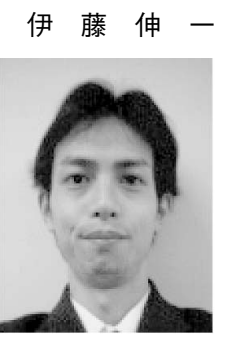

(非会員) 2004 年 3 月德島大学大学院工学研究科 博士前期課程修了。同年 4 月（株）ジェイジーエ ス入社。2006 年 4 月東京農工大学大学院生物シ ステム応用科学府博士後期課程入学, 現在に至る。 音楽心理学, 脳波分析, 感性工学などの研究に従 事。電子情報通信学会，日本生体医工学会会員。

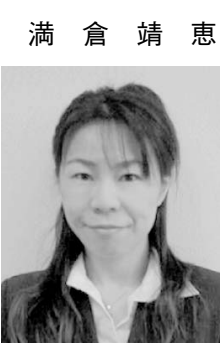

(正員) 1999 年 4 月徳島大学工学部知能情報工 学科助手。2001 年 9 月徳島大学大学院工学研究 科博士後期課程短縮修了。博士 (工学)。2003 年 4 月岡山大学教育学部技術科教育講師, 2006 年 1 月東京農工大学大学院助教授, 現在に至る。画像 処理, 脳波解析，信号処理分野の研究に従事。計 測自動制御学会, 信号処理学会正会員。

宮村（中村） 浩子（非会員） 2004 年 3 月お茶の水女子大学大

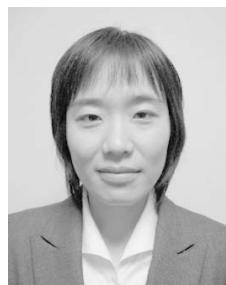
学院人間文化研究科博士課程修了。同年 4 月より 東京農工大学大学院生物システム応用科学教育部 助手。博士 (理学)。数值シミュレーションデー 夕の可視化，情報可視化などの研究に従事。情報 処理学会会員。

斎 藤 隆 文 (非会員) 1987 年東京大学大学院工学系研究科博

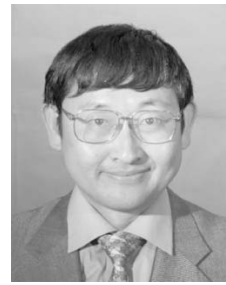
士課程満期退学，90 年修了。工学博士。 87 年日本 電信電話 (株) 入社, NTT 基礎研究所, ヒューマ ンインタフェース研究所勤務。9 97 年東京農工大学 工学部助教授, 現在, 同大学大学院生物システム 応用科学府教授。コンピュータグラフィックス，形 状処理，映像処理，可視化などの研究に従事。情 報処理学会，画像電子学会，ACM SIGGRAPH

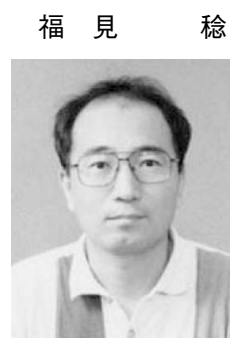

の会員。
稔（正員） 1987 年 3 月徳島大学大学院工学研究科 修士課程了。同年同大助手。講師，助教授を経て, 現在，同大学大学院ソシオテクノサイエンス研究 部教授。京大博士 (工学)。ディジタル信号処理, 生物型情報処理，ヒューマンセンシングなどの研 究に従事。1995 年計測自動制御学会論文賞，な ど。計測自動制御学会, 電子情報通信学会, シス テム制御情報学会, 情報処理学会, IEEE，など 